\title{
EFFECT OF FENOFIBRATE ADMINISTRATION AND ITS WITHDRAWAL ON THE KIDNEYS OF ADULT MALE ALBINO RATS (HISTOLOGICAL AND BIOCHEMICAL STUDIES)
}

\author{
By \\ Amany M. Abo-Ouf and Mona A. A. Arafa \\ Department of Anatomy and Embryology, Faculty of Medicine (Girls), Al-Azhar \\ University \\ amanymostafa.med@azhar.edu.eg or m_aouf2000@yahoo.com \\ monaabdellatef.med@azhar.edu.eg or mona.23875@gmail.com
}

\begin{abstract}
Background: Fenofibrate is among the drugs of choice for treatment of hypertriglyceridemia and low levels of high-density lipoprotein-cholesterol, both recognized as risk factors for cardiovascular disease .

Objective: Demonstrating the effect of fenofibrate administration and its withdrawal on the histological structure and function of the kidney in adult male albino rats .

Material and methods: Forty adult male albino rats were used in this work. They were divided equally into four groups; I-First control group (Group A), II- Second control group (Group B), III- Treated group (Group C) and IV- Recovery group (Group D). Each adult male albino rat of groups A and C was given $0.96 \mathrm{ml}$ of distilled water and $0.96 \mathrm{ml}$ of distilled water (Contained $3.6 \mathrm{mg}$ fenofibrate) respectively for six weeks. Each adult male albino rat of groups B and D was given $0.48 \mathrm{ml}$ of distilled water and $0.96 \mathrm{ml}$ of distilled water (Contained $3.6 \mathrm{mg}$ fenofibrate) respectively for six weeks, then, left for two weeks without treatment. The treatments were given once/day orally. The specimens were collected at two time intervals; at the end of the 6th week for groups A \&C and at the end of the 8th week for groups B \& D. The blood samples were collected for measuring urea, creatinine, MDA and SOD. The kidneys were used for light \& electron microscopic examinations, and morphometric study .
\end{abstract}

Results: Light and electron microscopic examination and morphometric studies demonstrated that fenofibrate induced various signs of degeneration, necrosis, inflammation and fibrosis. Biochemical study revealed that fenofibrate induced deterioration in the kidney functions which were reflected by significant increase in the serum levels of urea and creatinine. It also revealed significant increase in the oxidant parameters (MDA), and significant decrease in the antioxidant parameters (SOD). On fenofibrate withdrawal, most of the histological and all the biochemical effects were recovered.

Conclusion: Fenofibrate induced various deleterious changes in the histological structure and function of the kidney by inducing oxidative stress. These changes and oxidative stress were reversible on fenofibrate withdrawal .

Key words: animals, rat, fenofibrate, kidney, creatinine, oxidant, antioxidant 


\section{INTRODUCTION}

Lipids disorder is the principal cause of atherosclerosis which in turn the principal cause of cardiovascular disease. Cardiovascular disease represents the first cause of death and morbidity of the western countries and is continuously increasing also in new developing countries (Tarantino et al., 2017). Fenofibrate is one of the most commonly prescribed fibrates. It is given orally at a dose of 48 to $200 \mathrm{mg}$ daily (Yang and Keating, 2009 and Ahmad et al., 2017). Fibrates are a class of lipid-lowering medications primarily used as second-line agents behind statins (Sica, 2009).They are agonists of the peroxisome proliferator-activated receptors alpha (PPAR-a).They have been shown to stimulate the expression of genes involved in fatty acid and lipoprotein metabolism, resulting in a shift from hepatic fat synthesis to fat oxidation. This leads to a substantial reduction in serum triglycerides and an increase in highdensity lipoprotein cholesterol levels (Bonovas, et al., 2012). All of the fibrate drugs are absorbed rapidly and efficiently (>90\%) when given with a meal. The drugs are widely distributed through the body and its concentration in the liver, kidney, and intestine exceed the plasma level. About $60-90 \%$ of oral dose is excreted in the urine, with small amounts appearing in the feces (Brunton et al., 2011). The side effects of fibrate treatment include gastrointestinal complaints, gallstones, and skin reactions, all of which are tolerable and reversible. The most important side effect of fibrates is rhabdomyolysis (Cetinkaya et al., 2008 and $W u$ et al., 2009). Deterioration in renal function is not a much known adverse effect of fibrates. However, thirteen patients with acute renal failure associated to fibrates was detected (Polanco et al., 2009). Fenofibrate has been noted to afford reno protection in experimental diabetic models and hypertensive renal injury (Hou et al., 2010 and $\mathrm{Li}$ et al., 2010). From this view, the effect of fenofibrate on the kidneys is controversial.

The present work aimed to demonstrate the effect of fenofibrate administration and its withdrawal on the histological structure and function of the kidney, oxidant and antioxidant parameters in male albino rats.

\section{MATERIALS AND METHODS}

\section{Drug:}

Fenofibrate (Lipanthyl®) was available in capsule forms, manufactured by Minipharm for Pharmaceutical and Chemical Industries, 10th of RamadanEgypt under licence of laboratories Fournier- France. The human therapeutic dose ranged from 100 to $200 \mathrm{mg}$ twice daily (Sengupata, 2016). In this work, 200 $\mathrm{mg}$ of fenofibrate was used. The equivalent dose of adult rat was calculated according to the formula of (Paget and Barnes, 1964) to be $3.6 \mathrm{mg} / \mathrm{rat}$. The content of $300 \mathrm{mg}$ lipanthyl capsule was dissolved in $80 \mathrm{ml}$ of distilled water. So, the adult rat received $0.96 \mathrm{ml}$ of distilled water that contained $3.6 \mathrm{mg}$ of fenofibrate. The distilled water alone or the distilled water that contained the drug were given by gastric tube as a single oral daily dose for the control and treated rats respectively. 


\section{Animals:}

Forty adult male albino rats of local strain were used in this work. The average weight of the adult male rats was about $120 \mathrm{~g}$. They were obtained and provided by veterinary care by the animal house of Faculty of Medicine (Girls), Al- Azhar University during the year of 2018. The adult male albino rats were housed in stainless steel cages $(40 \times 27.5 \times 19.5 \mathrm{~cm})$. Each cage contained 5 adult male albino rats. The rats were observed and maintained on balanced water and diet (standard diet pellets- El-Nasr-company, Abo-Zaabal - Egypt). The rats were divided equally into 4 groups: first \& second control, treated and recovery groups.

I-First control group (Group A): Each rat was given $0.96 \mathrm{ml}$ of distilled water as a single oral daily dose for 6 weeks.

II-Second control group (Group B): Each rat was given $0.96 \mathrm{ml}$ of distilled water as a single oral daily dose for 6 weeks. Then, the distilled water was stopped for 2 weeks.

III-Treated group (Group C): Each rat was given $0.96 \mathrm{ml}$ of distilled water (Contained $3.6 \mathrm{mg}$ fenofibrate) as a single oral daily dose for 6 weeks.

IV-Recovery group (Group D): Each rat was given $0.96 \mathrm{ml}$ of distilled water (Contained $3.6 \mathrm{mg}$ fenofibrate) as a single oral daily dose for 6 weeks. Then, the distilled water that contained the drug was stopped for 2 weeks.

Collection of the specimens and preparation for examination:

The specimens were collected at two time intervals; after six weeks (Groups; A
\& C) and after eight weeks (Groups; B \& D). The rats were anesthetized under isoflurene. Blood samples were collected from the retro-orbital sinus of each rat by a fine capillary glass tube. The collected blood was centrifuged at $3000 \mathrm{rpm}$ for 10 minutes. The clean supernatant serum was aspirated by automatic pipette into epindorff tubes and kept frozen at -20 until the time of biochemical study. Immediately after blood collection, rats were sacrificed, and the two kidneys of each rat were excised and used for histological study (One kidney was prepared for light microscopic examination and morphometric study, and the other one was prepared for electron microscopic examination).

\section{I-Histological study:}

1- Light microscopic examination: The kidneys were fixed by immersion in $10 \%$ formalin for three days (Kiernan, 2001). The specimens were dehydrated in ascending grades of ethyl alcohol and cleared in benzene. The specimens were impregnated for three changes in paraffin and were finally embedded in paraffin wax. The paraffin blocks were cut into serial sagittal sections at 5 ?m thick with a rotary microtome. Successive transverse paraffin sections were attached to an albumenized glass slides. The hematoxylin and Eosin stain was used to study the kidney architectures (Bancroft and Gamble, 2013). The Masson's trichrome stain (Bancroft and Gamble, 2013) was used to demonstrate the collagen fibers. The images were taken by a microscope (Leica) DM750 
connected to a digital camera in Anatomy Department, Faculty of Medicine for Girls, Al-Azhar University, Cairo. Egypt.

2- Transmission electron microscopic examination: The cortices of the kidneys were cut into small pieces. The specimens were immediately fixed in cold glutraldehyde (5\%) for 24 hours and washed in $0.1 \mathrm{ml}$ phosphate buffer ( $\mathrm{pH}$ 7.2) for 20 minutes (3 changes), then post fixed with $1 \%$ osmium tetraoxide for 1.5 hours. The specimens were washed again in phosphate buffer, dehydrated in ascending grads of alcohol and embedded in epoxy resin. The semithin sections (1?m thick) were cut on an LKB ultratome, stained with toluidine blue, and examined by light microscope to determine the area that subjected to ultrathin cutting. The ultrathin sections (60 $\mathrm{nm}$ thick) were mounted on copper grids, and stained with uranyl acetate and lead citrate (Bancroft and Gamble, 2013). The ultrathin sections were examined using a transmission electron microscope (JEOL1010 EX II, Japan) at the Regional Mycology and Biotechnology Center, Al-Azhar University, Cairo, Egypt.

3- Morphometric study: The image analyser computer system Leica Qwin 500 (England) at the Regional Mycology and Biotechnology center, Al-Azhar University, Cairo, Egypt was used to evaluate the width of the Bowman's spaces of the studied groups by using hematoxylin and eosin stained sections. The ten slides of ten rats of each group were taken. Then, 5 intact renal corpuscles were randomly selected in each slide, at power field $\times 100$, to measure the widths of Bowman's spaces by measuring 4 widths for each Bowman's capsule. The surface area of collagen fibres of the studied groups was evaluated by using H\&E-stained sections, and was measured in 5 fields in each section by using magnification $\mathrm{x} 100$.

\section{II-Biochemical study:}

The biochemical study to measure urea, creatinine, MDA and SOD was done at the Regional Mycology and Biotechnology Center, Al-Azhar University, Cairo, Egypt.

1- Serum urea and creatinine were determined spectrophotometrically according to the methods of Jung et al. (1975) and Jaffe et al., (1980) respectively.

2- Oxidant marker; malondialdehyde (MDA) was determined by thiobarbituric acid reactive substances (TBARs) assay (Ciobica et al., 2012).

3- Antioxidant marker; superoxide dismutase (SOD) was measured by the percentage reaction inhibition rate of enzyme with WST-1 substrate (a water soluble tetrazolium dye) and xanthine oxidase using a SOD Assay Kit (FLUKA, 19160) (Trofin et al., 2014). 


\section{Statistical analysis:}

Statistical analysis of the measured width of the Bowman's space, collagen fibers, urea, creatinine, MDA and SOD of the studied groups were carried out using the SPSS statistical package. The data were analyzed (Expressed as means $\pm \mathrm{SD}$ ) and statistical significance was determined by using one-way ANOVA followed by a Tuckey post-Hoc test for multiple comparisons. $\mathbf{P}$ value $\leq 0.05$ were considered to be statistically significant (Mould, 1989).

\section{RESULTS}

\section{I-Control groups (Groups; A \& B):}

Light and electron microscopic examination of groups $\mathrm{A}$ and $\mathrm{B}$ showed insignificant differences, so their data were pooled together .

Light microscopic examination of the hematoxylin and eosin stained transverse sections of the kidneys of the groups A\&B showed that the renal cortices were consisted of renal corpuscles, proximal and distal convoluted tubules and interstitial tissues. The renal corpuscles consisted of renal glomeruli that were surrounded by Bowman's capsules. The glomeruli appeared as large cellular masses of basophilic nuclei and eosinophilic cytoplasm. The Bowman's capsules consisted of parietal and visceral layers of epithelial cells that were separated by the Bowman's spaces. The visceral layer of epithelial cells (Podocytes) lined the glomerular side of the Bowman's space. The parietal layer of epithelial cells lined the Bowman's capsule on the opposite side. The proximal convoluted tubules had narrow lumina and definite basement membranes. They were lined by single layers of cuboidal or columnar cells that had central rounded basophilic nuclei and extensive brush borders on their luminal surfaces. The distal convoluted tubules had wide lumina and definite basement membranes. They were lined by single layers of cuboidal cells that had central rounded basophilic nuclei. The interstitial tissues consisted of interstitial cells with basophilic nuclei and blood vessels (Fig. 1a). The kidney sections that were stained with Masson's trichrome stain showed normal distribution of collagen fibers in the parietal layer of the Bowman's capsule, the renal glomeruli, the basement membranes of the renal tubules, the interstitial tissues and the wall of the blood vessels (Fig. 2a).

Electron microscopic examination of the kidneys of the groups A \& B showed that the glomeruli consisted of network of capillaries covered by visceral layer of epithelial cells (Podocytes) and supported by modified smooth muscle cells called mesangial cells. The glomerular capillary lumina contained red blood cells and lined by endothelial cells lied on thin glomerular basement membranes. The endothelial cells had euchromatic nuclei with small clumps of heterochromatin and their cytoplasm formed thin sheets broken by numerous small circular pores or fenestrations. The glomerular basement membrane lied between the endothelial cells and the podocytes and between the mesangial cells and the podocytes. The podocytes had euchromatic nuclei with small clumps of heterochromatin and primary foot processes that divided into numerous secondary foot processes. The secondary foot processes were separated by gaps; the filtration slits. Thin membranes called filtration slit membranes bridged the gaps between the 
secondary foot processes. The mesangial cells had euchromatic nuclei with large clumps of heterochromatin (Figs. 3a \& 4a). The proximal convoluted tubules had thin basement membranes that had regular basal interdigitations. They were lined by cells that had brush borders that were composed of numerous closely packed microvilli. The proximal tubule cells had nearly rounded indented euchromatic nuclei with small clumps of heterochromatin. The nuclei had prominent eccentric nucleoli and welldefined nuclear envelopes with apparent nuclear pores. Their cytoplasm contained few lysosomes and numerous rounded or elongated mitochondria which were arranged in parallel with the basal interdigitations (Figs. 5a \& 6a). The distal convoluted tubules had thin basement membranes that had regular basal interdigitations. They were lined by cells that had nearly rounded or oval euchromatic nuclei with small clumps of heterochromatin. The nuclei had prominent eccentric nucleoli and welldefined nuclear envelopes with apparent nuclear pores. Their cytoplasm contained rounded or elongated mitochondria arranged in parallel with the basal interdigitations and pinocytic vesicles (Figs. 7a \& 8a). The interstitial tissues consisted of interstitial cells that had euchromatic nuclei with small clumps of heterochromatin and few collagen fibers. (Figs. 5a, 6a, 7a \& 8a).

Morphometric study revealed insignificant differences in the width of the Bowman's spaces and collagen fibers between the groups A, B and D (Table 1).

Biochemical study revealed insignificant differences in the levels of urea, creatinine, MDA and SOD between the groups A, B and D (Table 1).

\section{II- Treated group (Group C):}

Light microscopic examination of the hematoxylin and eosin stained transverse sections of the kidneys of group C showed that many renal corpuscles had wide Bowman's spaces. Some glomeruli were congested. Many proximal and distal convoluted tubules were hardly differentiated where the integrities of the brush borders of the proximal tubules were destroyed or lost and their Lumina became dilated. Some tubular cells appeared exfoliated. Other cells had vacuolated cytoplasm, nuclei with fading of its basophilia and shrunken deeply stained nuclei. The majority of the interstitial tissues were infiltrated by inflammatory cells, homogenous eosinophilic material and hemorrhage as compared to the control one (Fig. 1b) and (Fig.1a). The kidney sections that were stained with Masson's trichrome stain demonstrated apparent increase in the collagen fibers distribution in the parietal layer of the Bowman's capsule, the renal glomeruli, the basement membranes of the renal tubules, the wall of the blood vessels and the interstitial tissues as compared with the control one (Fig. 2b) and (Fig. 2a).

Electron microscopic examination of the kidneys of group $\mathbf{C}$ showed that the glomeruli consisted of network of capillaries covered by visceral layer of epithelial cells (Podocytes) and supported by modified smooth muscle cells called mesangial cells. Some mesangial cells had irregular nuclei with large clumps of heterochromatin and few cells had irregular, shrunken nuclei with condensed clumps of heterochromatin. The glomerular capillaries lined by endothelial cells lied on thick glomerular basement membranes. Some endothelial cells had irregular nuclei with condensed clumps of heterochromatin. The podocytes had irregular nuclei with large clumps of heterochromatin. The majority of the 
secondary foot processes were fused, the filtration slits appeared narrow and the filtration slit membranes couldn't be identified as compared with the control one (Figs. 3b \& 4b) and (Figs. 3a \& 4a). Some proximal convoluted tubules had ill-defined basement membranes and others had thick ones. Some of their cells had shrunken nuclei with condensed clumps of heterochromatin. Other cells had euchromatic nuclei with small clumps of heterochromatin and nuclear envelops with apparent nuclear pores. Their cytoplasm contained many lysosomes, degenerated and swollen mitochondria with destructed cristae. The majority of the basal interdigitations couldn't be detected. The microvilli appeared short and interrupted in certain places by areas of vacuolations as compared with the control one (Figs.5b \& 6b) and (Figs.5a \& 6a). Some distal convoluted tubules had wide tubular lumina, irregular basement membranes with few and irregular basal interdigitations. Some of their cells were exfoliated and had shrunken nuclei with condensed clumps of heterochromatin. Other cells had shrunken nuclei with condensed clumps of heterochromatin or euchromatic nuclei with small clumps of heterochromatin and nuclear envelops with apparent nuclear pores, vacuolated cytoplasm, and malarranged mitochondria as compared with the control one (Figs. $7 \mathbf{b} \quad \boldsymbol{\&} \quad \mathbf{8 b}$ ) and (Figs.7a \& 8a). The interstitial tissues consisted of interstitial cells and numerous collagen fibers. Some interstitial cells had nuclei with condensed clumps of heterochromatin as compared with the control one (Figs. 5b \& 8b) and (Figs. 5a, 6a, 7a \& 8a).

Morphometric study revealed significant increase in the width of the Bowman's spaces and collagen fibers of group $\mathrm{C}$ when compared with those of the groups; A, B and D (Table 1).
Biochemical study revealed significant increase in the levels of urea, creatinine and MDA and significant decrease in the level of SOD of group $\mathbf{C}$ when compared with those of groups A, B and D (Table 1).

\section{III- Recovery group (Group D):}

Light microscopic examination of the hematoxylin and eosin stained transverse sections of the kidneys of group D showed an improvement in the renal corpuscles, renal tubules and interstitial tissues. However, few exfoliated cells present and few renal corpuscles had wide Bowman's spaces as compared with groups A, B \&C (Fig. 1c) and (Figs. 1a \&1b). The kidney sections that were stained with Masson's trichrome stain demonstrated apparent decrease in the collagen fibers distribution in the parietal layer of the Bowman's capsule, the renal glomeruli, the basement membrane of the renal tubules, the wall of the blood vessels and the interstitial tissues than those of group $\mathbf{C}$ to be more or less similar to those of groups A \&B (Fig. 2c) and (Figs. 2a \& 2b).

Electron microscopic examination of the kidneys of group D showed that the renal glomeruli appeared more improved than those of group $\mathbf{C}$ and more or less similar to groups A \& B. However, fusions of few secondary foot processes were present in certain areas (Figs. 3c \& 4c), (Figs. 3b \& 4b) and (Figs. 3a \& 4a). The proximal convoluted tubules appeared more improved than those of group $\mathbf{C}$ and more or less similar to groups A\& B (Figs.5c \& 6c), (Figs. 5b \& 6b) and (Figs. 5a \& 6a). The distal convoluted tubules appeared more improved than those of group $\mathbf{C}$ and more or less similar to groups A\& B (Figs.7a \& 8a) and (Figs. 5a \& 5b). The interstitial tissues appeared more improved than those of group $\mathbf{C}$ and more 
or less similar to groups A\& B. However, few interstitial cells had euchromatic nuclei with large clumps of heterochromatin (Figs. 5c \& 7c), (Figs. 5b \& 8b) and (Figs. 5a, 6a, 7a \& 8a).

Morphometric study revealed insignificant difference in the width of the
Bowman's spaces and collagen fibers between the groups D, A and $\mathbf{B}$ (Table 1).

Biochemical study revealed insignificant difference in the levels of urea, creatinine, MDA and SOD between the groups $\mathbf{D}, \mathbf{A}$ and $\mathbf{B}$ (Table 1).

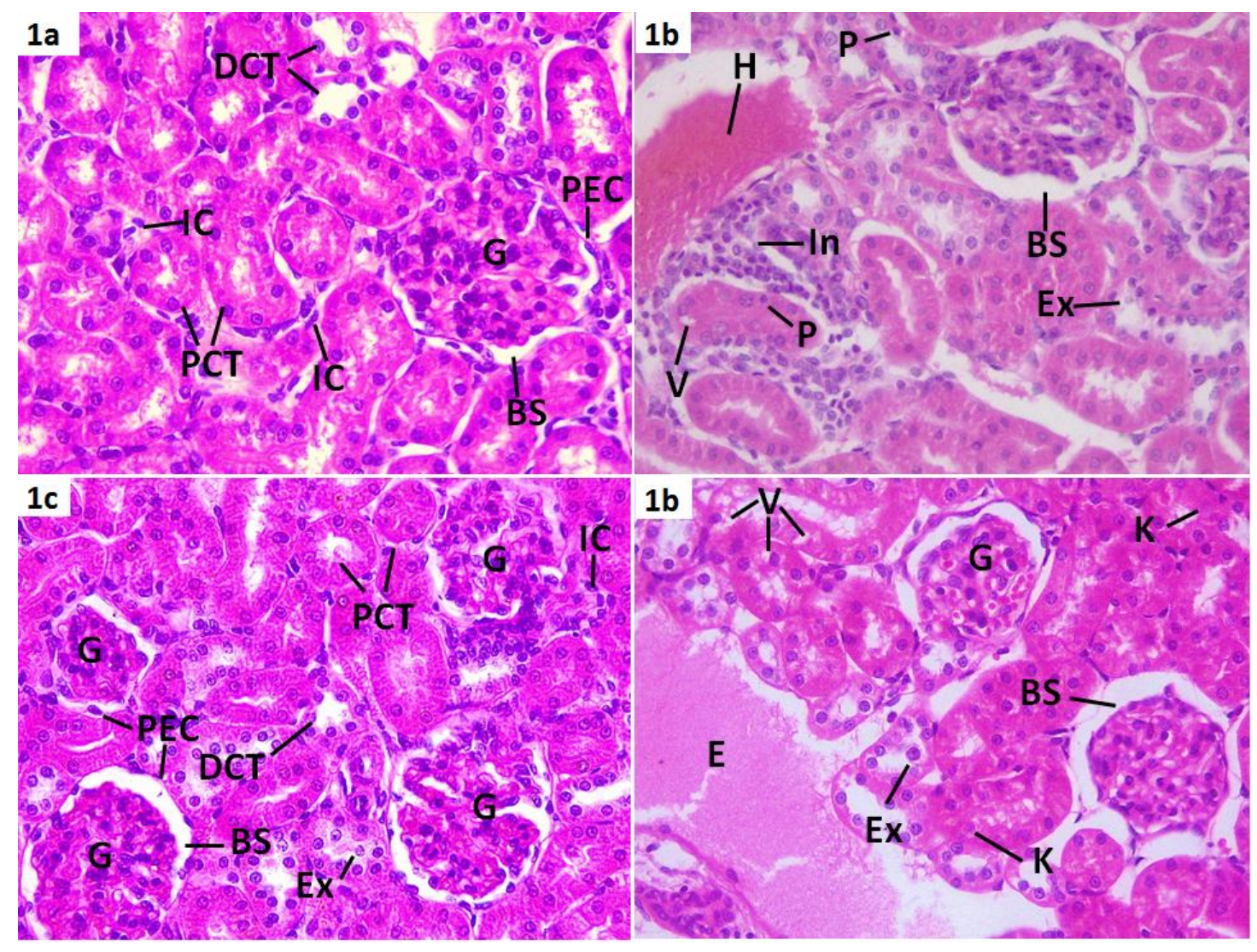

Fig. (1a): A photomicrograph of a transverse section of the kidney of adult male albino rats of groups $A \& B$ showed that the renal glomeruli $(\mathbf{G})$ appeared as large cellular masses of basophilic nuclei and eosinophilic cytoplasm. The Bowman's capsule formed of parietal layer of epithelial cells (PEC) which separated from the visceral layer by the Bowman's space (BS). The proximal convoluted tubules (PCT) were lined by single layers of cuboidal or columnar cells that had extensive brush borders. The distal convoluted tubules (DCT) were lined by single layers of cuboidal cells. The interstitial tissues consisted of interstitial cells (IC).

(H \& E X 400)

Fig. (1b): Two photomicrographs of a transverse section of the kidney of adult male albino rats of group $\mathrm{C}$ showed that the Bowman's spaces (BS) appeared wide. One glomerulus (G) was congested. Some tubular cells were exfoliated (Ex). Other cells had vacuolated cytoplasm (V), nuclei with fading of its basophilia $(\mathbf{K})$ and shrunken deeply stained nuclei (P). The interstitial tissues consisted of inflammatory cells (In), homogenous eosinophilic material (E) and hemorrhage (H).

(H \& E X 400) 
Fig. (1c): A photomicrograph of a transverse section of the kidney of adult male albino rats of group D showed that the Bowman's capsule was lined by parietal layer of epithelial cells (PEC). The glomeruli (G), the proximal convoluted tubules (PCT), the distal convoluted tubules (DCT) and the interstitial cells (IC) had normal appearance. Dilatation of the Bowman's space (BS) and few exfoliated tubular cells (Ex) were seen.

(H \& E X 400)
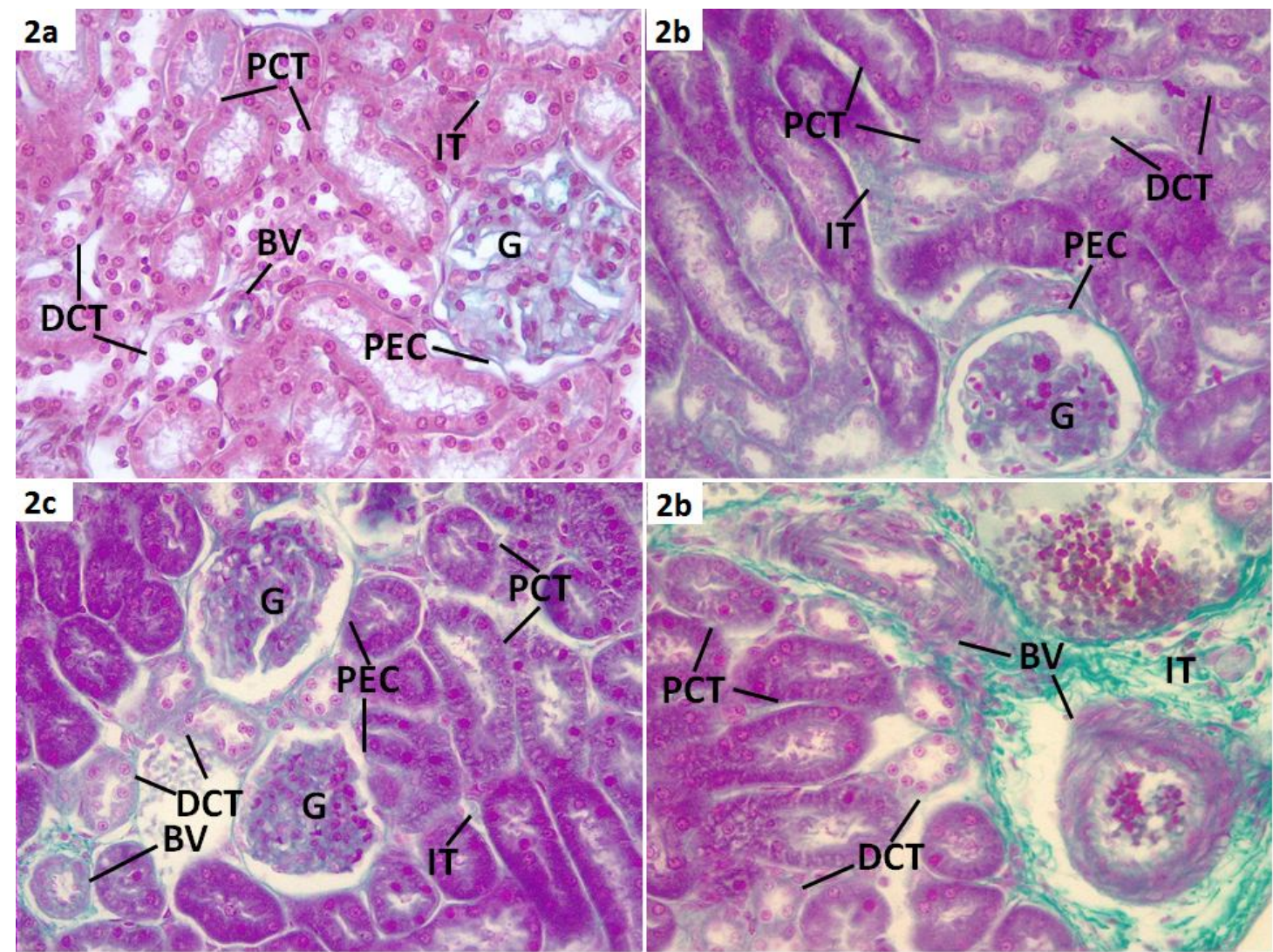

Fig. (2a): A photomicrograph of a transverse section of the kidney of adult male albino rats of groups $A \& B$ showed normal distribution of collagen fibers in the parietal epithelial layer of Bowman's capsule (PEC), the renal glomeruli (G), the basement membranes and brush borders of the proximal convoluted tubules (PCT) and the basement membranes of the distal convoluted tubules (DCT), the wall of the blood vessels (BV) and the interstitial tissues (IT).

(Masson's trichrome X 400)

Fig. (2b): Two photomicrographs of a transverse section of the kidney of adult male albino rats of group $\mathrm{C}$ showed apparent increase of collagen fibers distribution in the parietal epithelial layer of Bowman's capsule (PEC), the renal glomeruli (G), the basement membranes and brush borders of the proximal convoluted tubules (PCT) and the basement membranes of the distal convoluted tubules (DCT), the wall of the blood vessels (BV) and the interstitial tissues (IT).

(Masson's trichrome X 400)

Fig. (2c): A photomicrograph of a transverse section of the kidney of adult male albino rats of group D showed normal distribution of collagen fibers in the parietal epithelial layer of Bowman's capsule (PEC), the renal glomeruli (G), the basement membranes and brush borders of the proximal convoluted tubules (PCT) and the basement membranes of the distal convoluted tubules (DCT), the wall of the blood vessels (BV) and the interstitial tissues (IT).

(Masson's trichrome $X$ 400) 

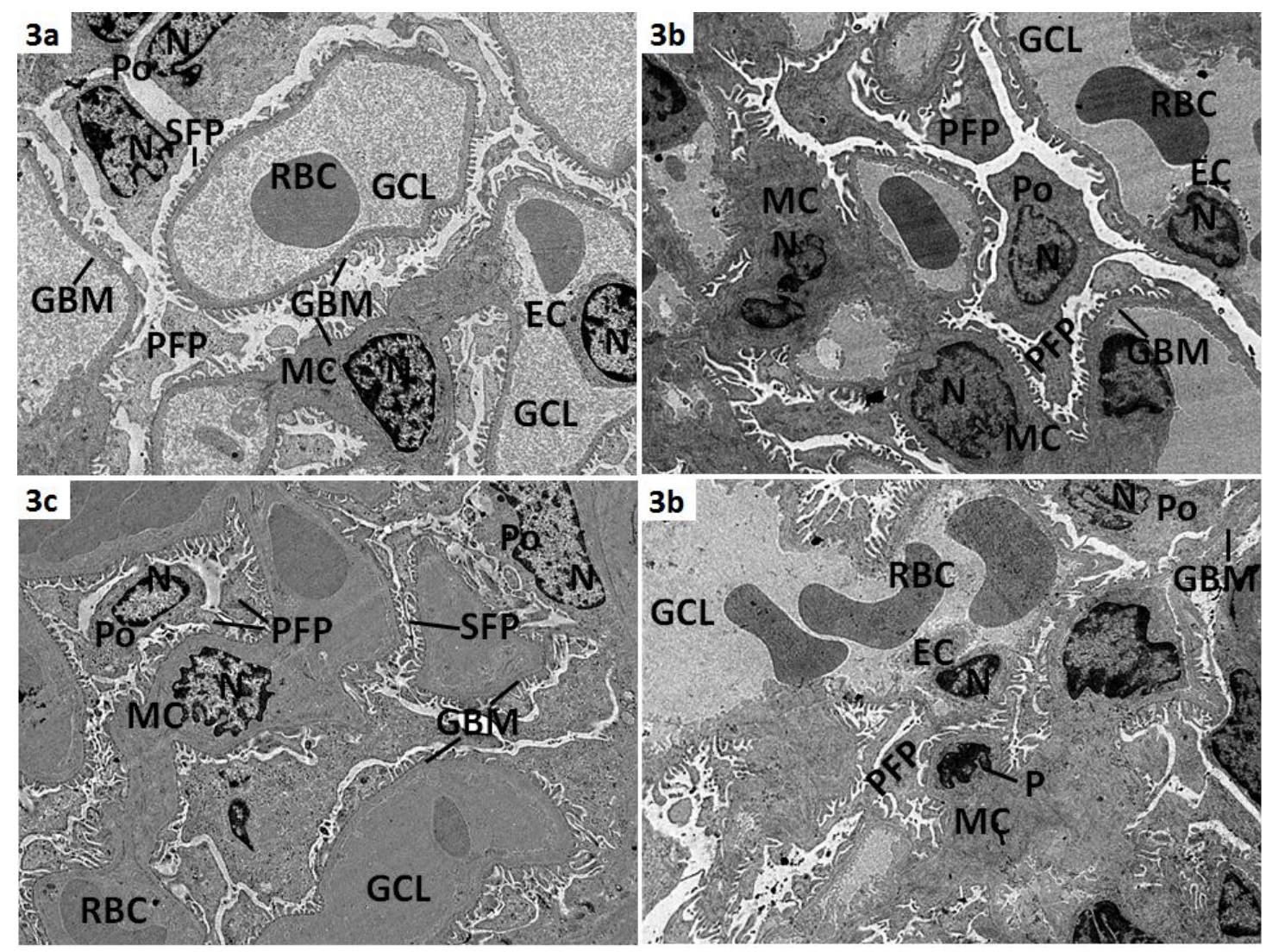

Fig. (3a): An electron micrograph of the kidney of adult male albino rats of groups A\& B showed that the glomerular capillary lumina (GCL) contained red blood cells (RBCs) and lined by endothelial cells (EC) that had euchromatic nuclei with small clumps of heterochromatin $(\mathbf{N})$. The thin glomerular basement membrane (GBM) was appeared. The mesangial cells (MC) had euchromatic nuclei with large clumps of heterochromatin (N). The podocytes (Po) had euchromatic nuclei with small clumps of heterochromatin $(\mathbf{N})$, primary foot processes (PFP) and secondary foot processes (SFP).

(TEM X 5000)

Fig. (3b): Two electron micrographs of the kidney of adult male albino rats of group $\mathrm{C}$ showed that the glomerular capillary lumina (GCL) contained red blood cells (RBCs) and lined by endothelial cells (EC) that had irregular nuclei with condensed clumps of heterochromatin $(\mathbf{N})$. The glomerular basement membranes (GBM) appeared thick in certain areas. Some mesangial cells (MC) had irregular nuclei with large clumps of heterochromatin (N) and other cells (MC) had irregular, shrunken nuclei with condensed clumps of heterochromatin (P). The podocytes (Po) had irregular nuclei with small clumps of heterochromatin (N) and primary foot processes (PFP).

(TEM X 5000)

Fig. (3c): An electron micrograph of the kidney of adult male albino rats of group D showed that the glomerular capillary lumina (GCL) contained red blood cells (RBCs). The glomerular basement membrane (GBM), the mesangial cells (MC) with its nucleus (N) and the podocytes (Po) with its nucleus (N), the primary foot processes (PFP) and the secondary foot processes (SFP) had normal appearance.

(TEM X 5000) 

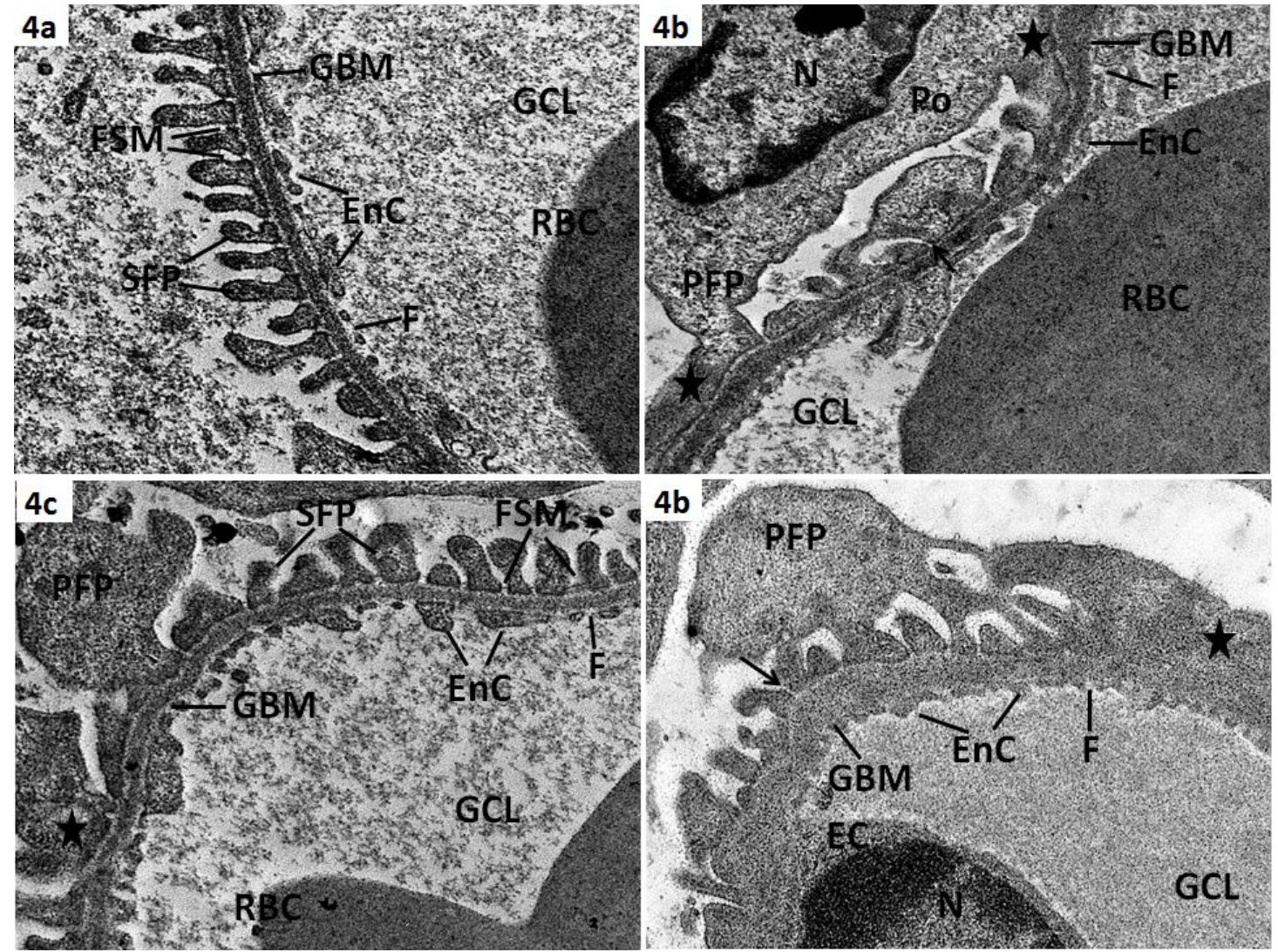

Fig. (4a): An electron micrograph of the kidney of adult male albino rats of groups A\& B showed that the glomerular capillary lumen (GCL) contained red blood cells (RBCs) and lined by endothelial cells that had cytoplasm (EnC) broken by numerous small fenestrations (F). The thin glomerular basement membrane (GBM) was appeared. The secondary foot processes (SFP) were separated by filtration slits that were bridged by filtration slit membranes (FSM).

(TEM X 25000)

Fig. (4b): Two electron micrographs of the kidney of adult male albino rats of group $\mathrm{C}$ showed that the glomerular capillary lumen (GCL) contained red blood cells (RBCs) and lined by an endothelial cell (EC) that had nucleus with large clumps of heterochromatin (N) and cytoplasm (EnC) that was broken by hardly detected fenestrations (F). The glomerular basement membranes (GBM) appeared thick. The podocyte (Po) had irregular nuclei with large clumps of heterochromatin (N), primary foot processes (PFP) and secondary foot processes which were fused in certain areas (star). The filtration slits appeared narrow and the filtration slit membranes couldn't be identified $(\rightarrow)$ in certain areas.

(TEM X 25000)

Fig. (4c): An electron micrograph of the kidney of adult male albino rats of group D showed that the glomerular capillary lumen (GCL) contained red blood cells (RBCs) and lined by endothelial cells that had cytoplasm (EnC) broken by numerous small fenestrations (F). The glomerular basement membrane (GBM), the primary foot processes (PFP), the secondary foot processes (SFP), the filtration slits and its overlying filtration slit membranes (FSM) had normal appearance. Few secondary foot processes were fused in certain areas (star).

(TEM X 25000) 

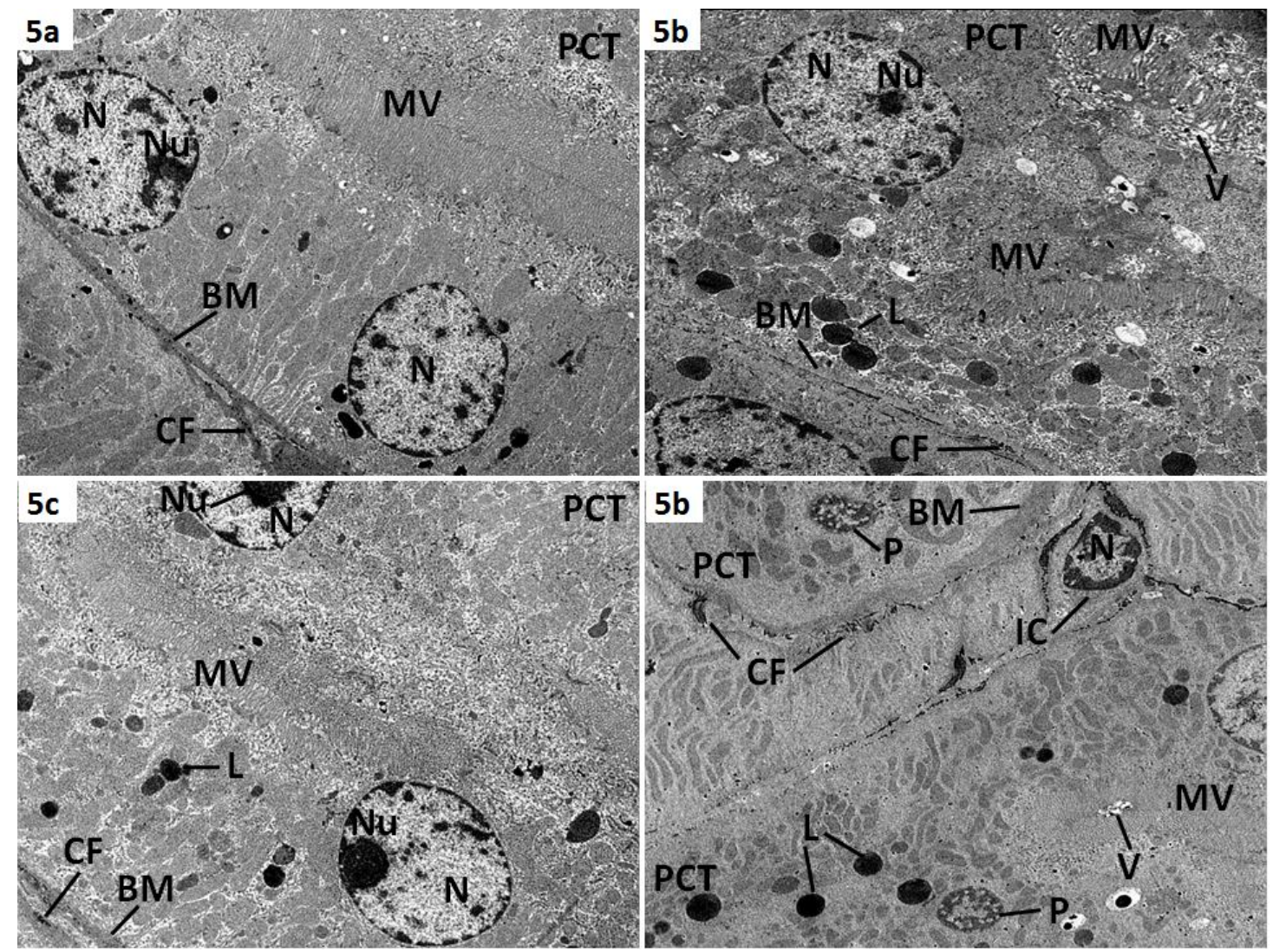

Fig. (5a): An electron micrograph of the kidney of adult male albino rats of groups A\&B showed that the proximal convoluted tubule (PCT) had thin basement membrane (BM). Their cells had numerous closely packed microvilli (MV) and indented euchromatic nuclei with small clumps of heterochromatin $(\mathbf{N})$ and prominent eccentric nucleoli $(\mathbf{N u})$. The interstitial tissue consisted of few collagen fibers (CF).

(TEM X 5000)

Fig. (5b): Two electron micrographs of the kidney of adult male albino rats of group $\mathrm{C}$ showed that the proximal convoluted tubule (PCT) had ill-defined and thick basement membrane (BM). The microvilli (MV) appeared short and interrupted by areas of vacuolations (V). Some cells had euchromatic nuclei with small clumps of heterochromatin (N) and eccentric nucleoli (Nu). Other cells had shrunken nuclei with condensed clumps of heterochromatin (P). Their cytoplasm contained many lysosomes $(\mathbf{L})$. The interstitial tissue consisted of numerous collagen fibers (CF) and an interstitial cell (IC) that had a nucleus with large clumps of heterochromatin $(\mathbf{N})$.

(TEM X 5000)

Fig. (5c): An electron micrograph of the kidney of adult male albino rats of group D showed that the proximal convoluted tubule (PCT) had thin basement membrane (BM). Their cells had numerous closely packed microvilli (MV), and euchromatic nuclei with small clumps of heterochromatin $(\mathbf{N})$ and prominent eccentric nucleoli $(\mathbf{N u})$. Their cytoplasm contained lysosomes (L). The interstitial tissue consisted of few collagen fibers (CF).

(TEM X 5000) 

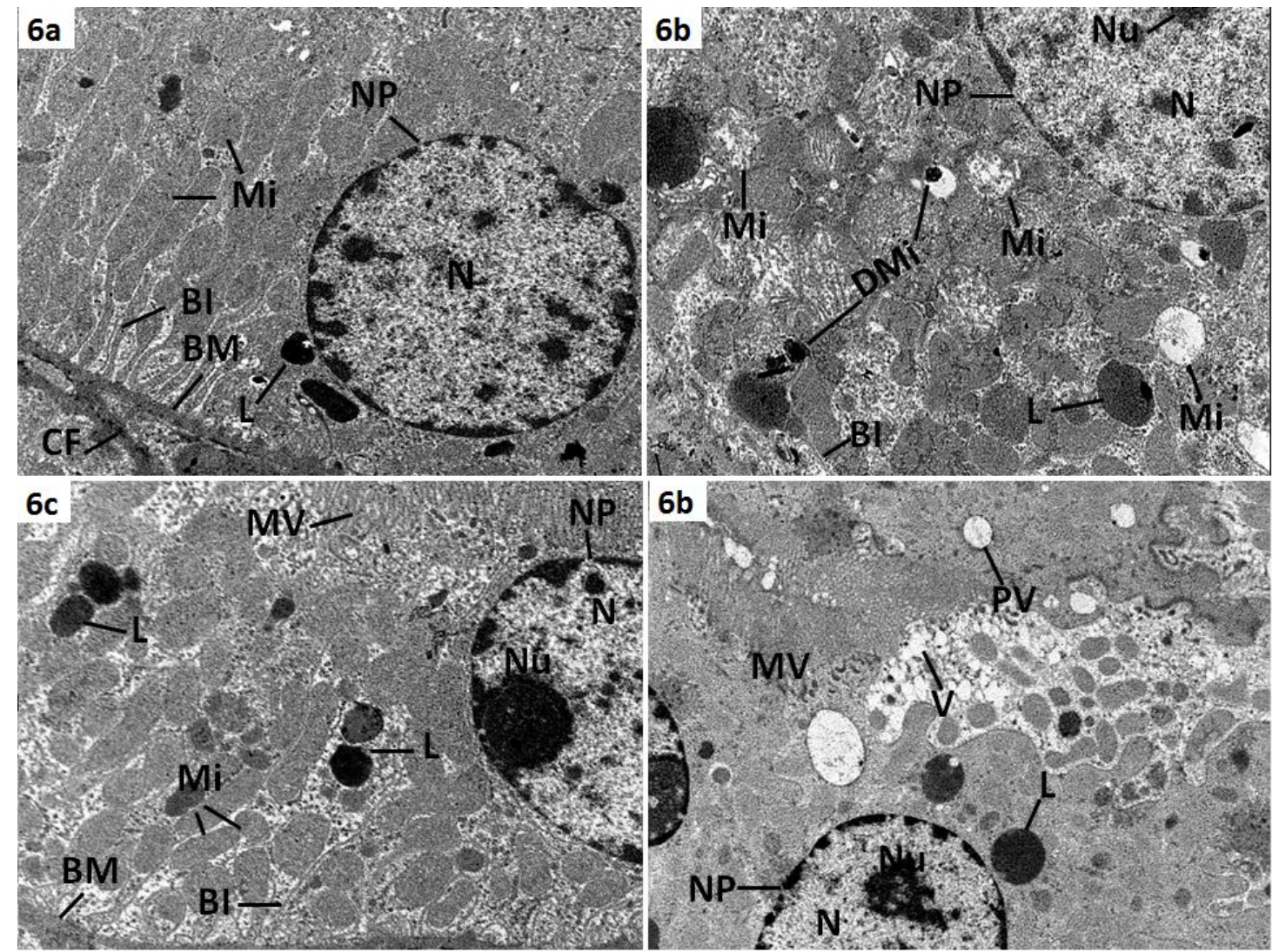

Fig. (6a): An electron micrograph of the kidney of adult male albino rats of groups A\&B showed that the proximal convoluted tubule had thin basement membrane (BM). Its cell had indented euchromatic nucleus with small clumps of heterochromatin (N) and welldefined nuclear envelopes with apparent nuclear pores (NP). Its cytoplasm contained lysosomes (L) and numerous rounded or elongated mitochondria (Mi) arranged parallel to the basal interdigitations (BI). The interstitial tissue consisted of few collagen fibers (CF). (TEMX 10000)

Fig. (6b): Two electron micrographs of the kidney of adult male albino rats of group C showed that the cells of the proximal convoluted tubule had euchromatic nuclei with small clumps of heterochromatin $(\mathbf{N})$, nucleoli $(\mathbf{N u})$ and nuclear envelops with apparent nuclear pores (NP). Their cytoplasm contained pinocytic vesicles (PV), lysosomes (L), degenerated (DMi) and swollen mitochondria with destructed cristae (Mi). The basal interdigitations (BI) were hardly detected. The microvilli (MV) appeared short and interrupted by areas of vacuolations $(\mathbf{V})$.

(TEM X 10000)

Fig. (6c): An electron micrograph of the kidney of adult male albino rats of group D showed that the proximal convoluted tubule had thin basement membrane (BM). The microvilli (MV) were closely packed together. One tubular cell had euchromatic nucleus with small clumps of heterochromatin $(\mathbf{N})$, prominent eccentric nucleolus $(\mathbf{N u})$ and welldefined nuclear envelope with apparent nuclear pores (NP). Its cytoplasm contained lysosomes (L) and numerous rounded or elongated mitochondria (Mi) arranged parallel to the basal interdigitations (BI).

(TEMX 10000) 

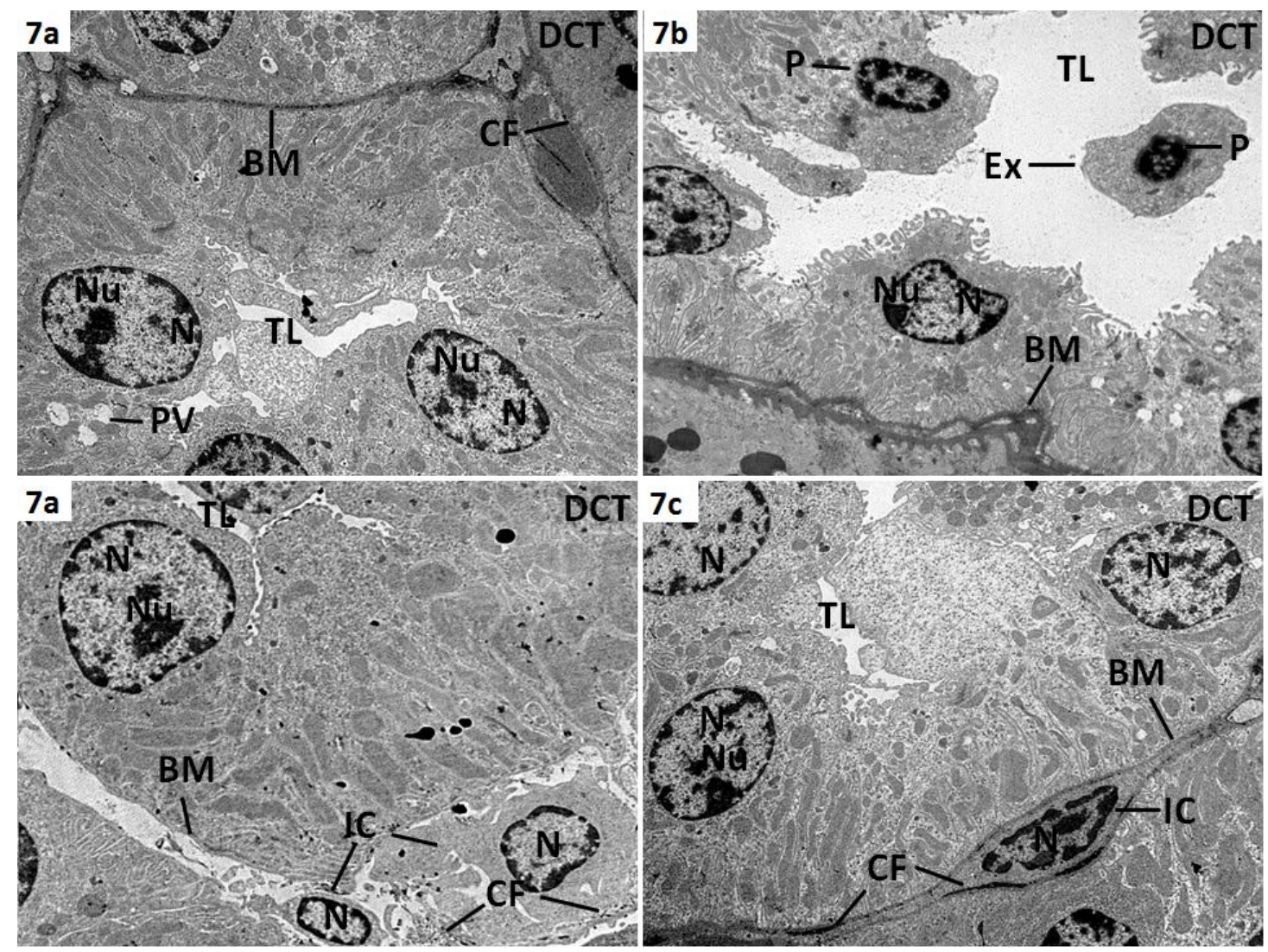

Fig. (7a): Two electron micrographs of the kidney of adult male albino rats of groups A\&B showed that the distal convoluted tubules (DCT) had thin basement membranes (BM). Their cells had euchromatic nuclei with small clumps of heterochromatin (N) and prominent eccentric nucleoli $(\mathbf{N u})$. Their cytoplasm contained pinocytic vesicles (PV). The tubular lumen (TL) was noticed. The interstitial tissue consisted of interstitial cells (IC) that had euchromatic nuclei with small clumps of heterochromatin (N) and few collagen fibers $(\mathbf{C F})$.

(TEM X 5000)

Fig. (7b): An electron micrograph of the kidney of adult male albino rat of group $C$ showed that the distal convoluted tubule (DCT) had wide tubular lumen (TL) and irregular basement membrane (BM). One of its cells was exfoliated (Ex) and had shrunken nucleus with condensed clumps of heterochromatin (P). Another cell had nucleus with condensed clumps of heterochromatin (P), other cells had euchromatic nuclei with small clumps of heterochromatin $(\mathbf{N})$ and eccentric nucleoli $(\mathbf{N u})$.

(TEM X 5000)

Fig. (7c): An electron micrograph of the kidney of adult male albino rats of group D showed that the distal convoluted tubule (DCT) had thin basement membranes (BM). Their cells had euchromatic nuclei with small clumps of heterochromatin $(\mathbf{N})$. The nuclei had prominent eccentric nucleoli (Nu) and well-defined nuclear envelopes with apparent nuclear pores (NP). The tubular lumen (TL) was noticed. The interstitial tissue consisted of an interstitial cell (IC) that had euchromatic nucleus with large clumps of heterochromatin $(\mathbf{N})$ and collagen fibers (CF)

(TEM X 5000) 

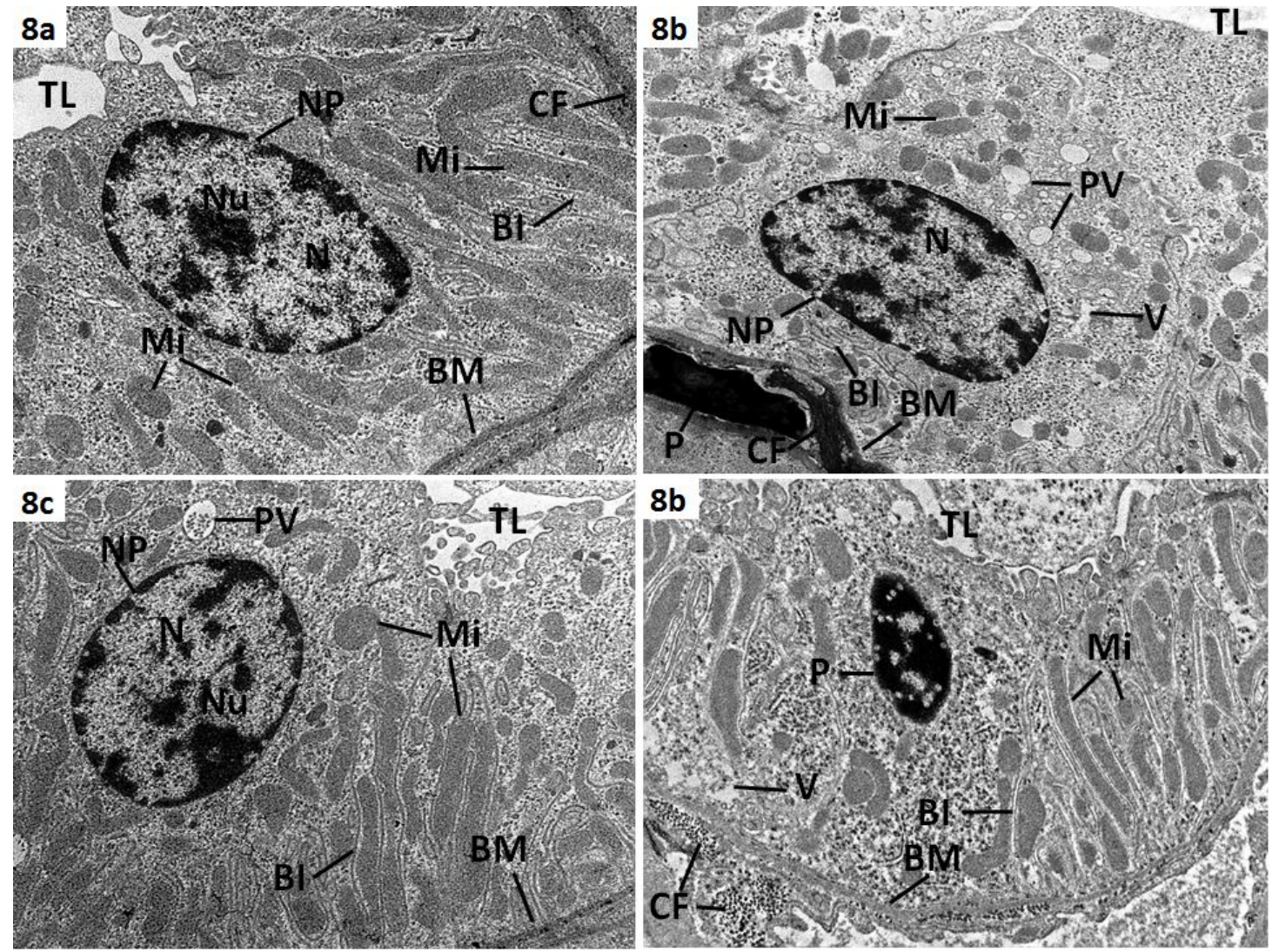

Fig. (8a): An electron micrograph of the kidney of adult male albino rats of groups A\&B showed that the distal convoluted tubule had thin basement membrane (BM). Its cell had euchromatic nucleus with small clumps of heterochromatin $(\mathbf{N})$. The nucleus had prominent eccentric nucleolus $\mathbf{( N u )}$ and well-defined nuclear envelope with apparent nuclear pores (NP). Its cytoplasm contained rounded or elongated mitochondria (Mi) arranged parallel to the basal interdigitations (BI). The tubular lumen (TL) was noticed. The interstitial tissue consisted of few collagen fibers (CF).

(TEM X 10000)

Fig. (8b): Two electron micrographs of the kidney of adult male albino rats of group $\mathrm{C}$ showed that one distal convoluted tubule had irregular basement membrane (BM), few and irregular basal interdigitations (BI) in certain areas, its cell had euchromatic nucleus with small clumps of heterochromatin (N) with apparent nuclear pores (NP), cytoplasmic vacuoles (V), mal-arranged mitochondria (Mi) and pinocytic vesicles (PV). The other tubule had regular basement membrane (BM) and its cell had shrunken nucleus with condensed clumps of heterochromatin $(\mathbf{P})$, cytoplasmic vacuoles $(\mathbf{V})$, mitochondria (Mi) arranged parallel to the basal interdigitations (BI). The tubular lumen (TL) was noticed. The interstitial tissue consisted of numerous collagen fibers (CF) and an interstitial cell that had nucleus with condensed clumps of heterochromatin (P).

(TEM X 10000)

Fig. (8c): An electron micrograph of the kidney of adult male albino rats of group D showed that the distal convoluted tubule had thin basement membrane (BM). Its cell had euchromatic nucleus with small clumps of heterochromatin $(\mathbf{N})$. The nucleus had prominent eccentric nucleolus (Nu) and well-defined nuclear envelopes with apparent nuclear pores (NP). Their cytoplasm contained pinocytic vesicles (PV) and rounded or elongated mitochondria (Mi) arranged parallel to the basal interdigitations (BI). The tubular lumen (TL) was noticed.

(TEM X 10000) 
Table (1): Levels of, urea, creatinine, MDA and SOD, width of Bowman's space and percentage of collagen fibers of studied groups

\begin{tabular}{|c|c|c|c|c|c|c|c|}
\hline \multicolumn{2}{|c|}{ Parameters } & $\mathbf{A}$ & B & $\mathbf{C}$ & $\mathbf{D}$ & $\begin{array}{l}\text { Test } \\
\text { value } \\
*\end{array}$ & $\begin{array}{l}P \text { - } \\
\text { value }\end{array}$ \\
\hline $\begin{array}{l}\text { Urea } \\
(\mathrm{mg} / \mathrm{dl})\end{array}$ & $\begin{array}{l}\text { Mean } \pm \text { SD } \\
\text { Range }\end{array}$ & $\begin{array}{l}21.80 \pm 5.33 \\
15-30\end{array}$ & $\begin{array}{l}21.90 \pm 5.38 \\
15-31\end{array}$ & $\begin{array}{l}39.70 \pm 2.83 \\
36-45\end{array}$ & $\begin{array}{l}22.10 \pm 5.86 \\
14-30\end{array}$ & 31.660 & \multirow{6}{*}{0.001} \\
\hline $\begin{array}{l}\text { Creatinine } \\
\text { (mg/dl) }\end{array}$ & $\begin{array}{l}\text { Mean } \pm S D \\
\text { Range }\end{array}$ & $\begin{array}{l}0.58 \pm 0.07 \\
0.5-0.7\end{array}$ & $\begin{array}{l}0.58 \pm 0.08 \\
0.5-0.7\end{array}$ & $\begin{array}{l}1.07 \pm 0.11 \\
0.9-1.2\end{array}$ & $\begin{array}{l}0.59 \pm 0.09 \\
0.5-0.76 \\
\end{array}$ & 79.392 & \\
\hline $\begin{array}{l}\text { MDA } \\
(\mathrm{mmol} / \mathrm{l})\end{array}$ & $\begin{array}{l}\text { Mean } \pm \text { SD } \\
\text { Range }\end{array}$ & $\begin{array}{l}25.28 \pm 1.70 \\
22-27.6\end{array}$ & $\begin{array}{l}25.28 \pm 1.70 \\
22-27.6\end{array}$ & $\begin{array}{l}37.17 \pm 2.78 \\
33-42\end{array}$ & $\begin{array}{l}25.78 \pm 2.61 \\
22-31.6\end{array}$ & 67.940 & \\
\hline $\begin{array}{l}\text { SOD } \\
\text { (U/ml) }\end{array}$ & $\begin{array}{l}\text { Mean } \pm \text { SD } \\
\text { Range } \\
\end{array}$ & $\begin{array}{l}2.09 \pm 0.30 \\
1.86-2.64 \\
\end{array}$ & $\begin{array}{l}2.09 \pm 0.31 \\
1.86-2.74 \\
\end{array}$ & $\begin{array}{l}1.20 \pm 0.33 \\
0.87-1.77 \\
\end{array}$ & $\begin{array}{l}1.99 \pm 0.29 \\
1.57-2.64 \\
\end{array}$ & 19.669 & \\
\hline CF\% & $\begin{array}{l}\text { Mean } \pm \text { SD } \\
\text { Range }\end{array}$ & $\begin{array}{l}7.70 \pm 3.76 \\
2.14-12.32 \\
\end{array}$ & $\begin{array}{l}7.77 \pm 3.78 \\
2.14-12.22 \\
\end{array}$ & $\begin{array}{l}34.17 \pm 8.58 \\
20.35-46.71\end{array}$ & $\begin{array}{l}7.97 \pm 4.08 \\
2.31-14.22 \\
\end{array}$ & 58.474 & \\
\hline BS & $\begin{array}{l}\text { Mean } \pm \text { SD } \\
\text { Range }\end{array}$ & $\begin{array}{l}11.44 \pm 1.83 \\
9.14-14.5\end{array}$ & $\begin{array}{l}11.40 \pm 1.81 \\
9.13-14.5 \\
\end{array}$ & $\begin{array}{l}25.14 \pm 8.91 \\
9.75-34.64 \\
\end{array}$ & $\begin{array}{l}11.60 \pm 2.09 \\
9.17-15.5\end{array}$ & 20.664 & \\
\hline \multicolumn{8}{|c|}{ Post Hoc Analysis using LSD test } \\
\hline \multirow{2}{*}{\multicolumn{2}{|c|}{ Parameters }} & \multicolumn{6}{|c|}{ P-values } \\
\hline & & A vs B & A vs $\mathbf{C}$ & A vs D & B vs $\mathbf{C}$ & B vs $\mathbf{D}$ & C vs D \\
\hline \multicolumn{2}{|c|}{ Urea (mg/dl) } & 0.965 & \multirow{6}{*}{0.001} & 0.894 & \multirow{6}{*}{0.001} & 0.929 & \multirow{6}{*}{0.001} \\
\hline \multicolumn{2}{|c|}{ Creatinine (mg/dl) } & 0.979 & & 0.738 & & 0.757 & \\
\hline \multicolumn{2}{|c|}{ MDA (mmol/li) } & 1.000 & & 0.623 & & 0.621 & \\
\hline \multicolumn{2}{|c|}{ SOD (U/ml) } & 1.000 & & 0.472 & & 0.472 & \\
\hline \multicolumn{2}{|l|}{ CF\% } & 0.977 & & 0.912 & & 0.935 & \\
\hline \multicolumn{2}{|l|}{ BS } & 0.983 & & 0.941 & & 0.924 & \\
\hline
\end{tabular}

*; One Way ANOVA - MDA; Malondialdehyde- SOD; Superoxide dismutase- CF; Collagen fibers- BS; Bowman's space- A; First control group- B; Second control group- C; Treated group- D; Recovery group

\section{DISCUSSION}

In the present work, light and electron microscopic examination and morphometric study of the kidney of fenofibrate treated adult male albino rat demonstrated various signs of degeneration and necrosis in the form of significant widening of the Bowman's spaces of the renal corpuscles, fusion of the podocyte foot processes, narrowing of the filtration slits and ill-defined filtration slit membranes, exfoliation of the cells of the renal tubules, Loss of integrity and distortion of brush borders of the proximal convoluted tubules, cytoplasmic vacuoles, presence of degenerated and swollen mitochondria with destructed cristae, malarranged mitochondria and nuclear changes in the form of karyolysis and pyknosis. Also various signs of inflammation and fibrosis were demonstrated in the form of significant increase in the collagen fibers, presence of interstitial edema, inflammatory cellular infiltration and thickening of the glomerular and tubular basement membranes. These findings were in line with Park et al. (2017) who analyzed the histopathological results from the biopsies of patients who were treated with fenofibrate. The kidney biopsies showed toxic tubular damage in the form of cytoplasmic degeneration affecting the 
proximal tubule cells and the presence of prominent hyaline granule. Moreover, these findings coincided with the findings of many authors on different organs rather than the kidney as Ohta et al. (2009) who stated that fenofibrate induced hepatocellular hypertrophy, eosinophilia and slight single cell necrosis in male rats. Also, Ahmad et al. (2017) reported that fenofibrate $160 \mathrm{mg}$ induced chronic cholestasis and mild inflammation in the liver of 41 year-old male. Also, Okada et al. (2009) stated that fenofibrate induced microscopic changes in the soleus muscle of rats in the form of degeneration/necrosis of muscle fibers, infiltration of leukocytes and fibrosis. Also, Katoa et al. (2011) reported that fenofibrate monotherapy in a patient with chronic myelogenous leukemia, induced histological changes in the psoas muscle in the form of irregular fiber sizes, degenerating fibers surrounding the inflammatory reaction, and fiber necrosis.

In the present work, glomerular congestion and interstitial hemorrhage were present. These findings coincided with Ali et al. (2009) and (Schelleman et al. (2010) who reported that fibrates were metabolized by CYP3A4 and appeared to increase the risk of gastrointestinal bleeding, and fenofibrate inhibited platelet aggregation in the whole blood.

In the present work, the effect of fenofibrate on the histological structure of the kidney was confirmed by measuring serum urea and creatinine levels as indicators of kidney function. Significant increase in their levels was detected, demonstrating impairment in the kidney function. This finding coincided with Ronco et al. (2010) who reported that the abnormally high levels of serum creatinine and urea were consistent with the impaired kidney function. Also, Forsblom et al. (2010) and Sagheb et al. (2014) reported concomitant decreases in creatinine clearance and estimated glomerular filtration rat and increase of cystatin $\mathrm{C}$ in type 2 diabetic patients during fenofibrate treatment. Serum cystatin $\mathrm{C}$ was not superior to serum creatinine in the early detection of renal dysfunction in critically ill patients. Also, Attridge et al. (2012) and Mychaleckyj et al. (2012) stated that fenofibrate increased serum creatinine. Fenofibrate-associated nephrotoxicity was defined as a change in serum creatinin concentration of at least $0.2 \mathrm{mg} / \mathrm{dL}$. Also, Kostapanos et al. (2013) stated that most clinical studies showed a rapid (within weeks) raising effect of fenofibrate on serum creatinine levels. This was often accompanied by declined estimated glomerular filtration rate. In addition, Kim et al. (2017) investigated the effects of 1-12 months of fenofibrate treatment in patients with hypertriglyceridemia who did not have a history of cardiovascular disease. These patients were frequently seen in primary care settings and showed a significant increase in their mean serum creatinine levels, and a significant decrease in their mean estimated glomerular filtration values following treatment. Moreover, Park et al. (2017) reported that fenofibrate therapy significantly increased blood creatinine levels. The elevation occurred in early phase of the medication.

In the present work, kidney affection by fenofibrate was determined by measurement of MDA as a marker of lipid peroxidation and SOD as one of antioxidant parameters. Significant 
increase in MDA and significant decrease in SOD were induced by fenofibrate, denoting oxidative stress that led to tissue damage. This finding was in line with Nishimura et al. (2008) who reported that PPARa agonists markedly induced hydrogen peroxide (H2O2)-generating enzymes, such as acyl-coenzyme A (CoA) oxidase and cytochrome $\mathrm{P} 450$ 4A, resulting in increased levels of $\mathrm{H} 2 \mathrm{O} 2$, leading to lipid peroxidation and oxidative DNA damage. Also, Ozbek (2012) showed that oxidative caused tissue damage by different mechanisms including promoting lipid peroxidation, DNA damage, and protein modification. Also, Melekh et al. (2017) stated that lipid peroxidation and antioxidant enzyme activity play a key role in inflammation development. In addition, Mokhtari et al. (2017) reported that oxidative stress had led to accelerate the renal damage progression by inducing cytotoxicity. ROS stimulated oxidized proteins and DNA and lipid peroxidation that caused an inflammatory cascade by inflammatory cytokines, containing $\mathrm{TNF}-\alpha$, via the activation of $\mathrm{NF}-\kappa \mathrm{B}$. Activated $\mathrm{NF}-\kappa \mathrm{B}$ began signalling pathways contributed to renal fibrosis. Another possible cause of fenofibrate induced kidney injury could be explained by McQuade et al. (2008) who reported that fenofibrate might impair the generation of vasodilatory prostaglandins, leading to decreased dilation of the afferent arteriole; this compromises glomerular capillary pressure and reduced the perfusion of the kidneys.

In the present work, stoppage of fenofibrate treatment for 2 weeks led to reversibility of most deleterious effects on the histological structure of the kidney and complete reversibility of all biochemical parameters. This finding coincided with Danis et al. (2010) who reported rapid improvement in renal function on the third day after discontinuation of fenofibrate therapy. Also, Mychaleckyj et al. (2012) reported that the fenofibrate-associated on-trial increases in serum creatinine and cystatin $\mathrm{C}$ were reversible, and the reversal was complete after 51 days offdrug.

\section{CONCLUSION}

Fenofibrate induced various deleterious changes in the histological structure and function of the kidney by inducing oxidative stress. These changes and oxidative stress were reversible on fenofibrate withdrawal.

\section{RECOMMENDATION}

Renal function of all patients who undergo fenofibrate treatment should be monitored, and any detectable deterioration requires rapid withdrawal of the drug.

\section{ACKNOWLEDGMENT}

The authors like to express their deep gratitude to Dr. Mahmoud Mohammed Al-A'sar, the Regional Mycology and Biotechnology Center, AlAzhar University, Cairo, Egypt, for his cordial help and work on the biochemical study of this work.

\section{REFERENCES}

1. Ahmad, J.; Odin, J.; Hayashi, P.H.; Chalasani, N.; Fontana, R.J.; Barnhart, H.; Elizabeth T. Cirulli, E.T.; Kleiner, D.E. and Hoofnagle, J.H. (2017): Identification and Characterization of Fenofibrate-Induced Liver Injury. J. Digestive Diseases and Sciences; 62(12): 3596-3604.

2. Ali, F.Y.; Armstrong, P.C.J.; Dhanji,A.A.; Tucker, A.T.; Paul-Clark,M.J.; Mitchell, J.A. and Warner, T.D. (2009): Antiplatelet 
actions of statins and fibrates are mediated by PPARs. Arterioscler. Thromb. Vasc. Biol.; 29:706-711.

3. Attridge, R.L.; Linn, W.D.; Ryan, L.; Koeller, J. and Frei, C.R. (2012): Evaluation of the incidence and risk factors for development of fenofibrate-associated nephrotoxicity. J. Clin. Lipidol.; 6(1):19-26.

4. Bancroft, J. D. and Gamble, M. (2013): Theory and practice of histological techniques. 6th ed., Elsavier Health Sciences, Pbl. Churchill Livingstone, London, Edinburgh, New York. Philadelphia, St. Louis Sydney, Toronto, pp. 125-158.

5. Bonovas, S.; Nikolopoulos, G.K. and Bagos, P.G. (2012): Use of fibrates and cancer risk: a systematic review and meta-analysis of 17 long-term randomized Placebo-controlled trials. PLOS ONE 7(9): 45259-45260.

6. Brunton, L.L.; Chabner, B.A. and Knollmann, B.C. (2011): Goodman \& Gilman's: the pharmacological basis of therapeutics. 12th ed. New York Chicago San Francisco Lisbon London, pp. 902-903.

7. Cetinkaya, R.; Uyanik, A. and Yildrim, R. (2008): Fenofibrate monotherapy-induced rhabdomyolysis in a patient with type-2 diabetes. Indian J. Med. Sci.; 62:485-459.

8. Ciobica, A.; Olteanu, Z.; Padurariu, M. and Hritcu, L. (2012): The effects of pergolide on memory and oxidative stress in a rat model of Parkinson's disease. J. Physiol. Biochem.; 68: 59-69.

9. Danis, R.; Akbulut, S.; Ozmen, S. and Arikan, S. (2010): Rhabdomyolysis-induced acute renal failure following fenofibrate therapy: a case report and literature review. Case Reports in Medicine; 1-3.

10. Forsblom, C.; Hiukka, A.; Leinonen, E.S.; Sundvall, J.; Groop, P. and Taskinen, M. (2010): Effects of long-term fenofibrate treatment on markers of renal function in type 2 diabetes. Diabetes Care; 33 (2):215-220.

11. Hou, X.; Shen, Y.H.; Li, C.; Wang, F.; Zhang, C.; Bu, P. and Zhang, Y. (2010): PPARa agonist fenofibrate protects the kidney from hypertensive injury in spontaneously hypertensive rats via inhibition of oxidative stress and MAPK activity. Biochem. Biophys. Res. Commun.; 394:653-659.

12. Jaffe, M.; Bergman, A. and Ledyard, P. (1980): Effect of detergent on kinetic Jaffemethod assay for creatinine. Clin. Chem.; 26: 1729-1732.

13. Jung, D.; Briggs, N.; Erickson, J. and Ledyard, P. (1975): New colorimetric reaction for end point continues flow and kinetic measurement of urea. Clin. Chem.; 21: 11-36.

14. Katoa, K.; Nagaseb, A.; Matsudac, M.; Katoa, Y.; Onoderad, K.; Kawakamia, T.; Higuchia, M.; Iwasakie, Y.; Taniguchif, M. and Hiroyuki Furukawa, H. (2011): Rhabdomyolysis associated with fenofibrate monotherapy in a patient with chronic myelogenous leukemia -case rep. Gastroenterol.; 5:492-496.

15. Kieranan, J. A. (2001): Histological \& histochemical methods. 3rded. Pbl. Oxoford University Press, London, NewYork, New Delhi, pp. 103- 162.

16. Kim, S.; Ko, K.; Park, S.; Lee, D.R. and Lee, J. (2017): Effect of fenofibrate medication on renal function. Korean J. Fam. Med.; 38(4): 192-198.

17. Kostapanos, M.S.; Florentin, M. and Elisaf, M.S (2013): Fenofibrate and the kidney: an overview. European Journal of Clinical Investigation; 43( 5): 522-531.

18. Li, L., Emmett, N.; Mann, D. and Zhao, X. (2010): Fenofibrate attenuates tubule-interstitial fibrosis and inflammation through suppression of nuclear factor- $\mathrm{\kappa B}$ and transforming growth factor- $\beta 1 / \mathrm{Smad} 3$ in diabetic nephropathy. Exp. Biol. Med.; 235:383-391.

19. McQuade, C.R.; Griego, J.; Anderson, J. and Pai, A.B. (2008): Elevated serum creatinine levels associated with fenofibrate therapy. Am. J. Health Syst. Pharm.; 65:138141.

20. Melekh, B.; Ilkiv, I.; Lozynskyi, A. and Alexander Sklyarov, A. (2017): Antioxidant enzyme activity and lipid peroxidation in rat liver exposed to celecoxib and lansoprazole under epinephrine-induced stress. Journal of Applied Pharmaceutical Science; 7 (10): 094099. 
21. Mokhtari,Z.; Hekmatdoost, A. and Nourian, M. (2017): Antioxidant efficacy of vitamin D. Journal of Parathyroid Disease; 5(1):11-16.

22. Mould, R.F. (1989): Introductory medical statistics. 2nded. Pbl. Adam Hilger, Bristol and Philadelphia, pp. 17-26.

23. Mychaleckyj, J.C.; Craven, T. and Nayak, U. (2012): Reversibility of fenofibrate therapyinduced renal function impairment in ACCORD type 2 diabetic participants. Diabetes Care; 25:1008-1014.

24. Nishimura, J.; Dewa, Y.; Okamura, T.; Jin, M.; Saegusa, Y.; Kawai, M.; Umemura,T.; Shibutani, M. and Mitsumori, K. (2008): Role of Nrf2 and oxidative stress on fenofibrate-induced hepatocarcinogenesis in rats. Toxicological Sciences; 106(2): 339-349.

25. Ohta, t.; Masutom, N.; Tsutsui, N.; Sakairi, T.; Mitchell, M.; Milburn, M.V.; Ryals, J.A.; Beebe, K.D. and Guo, L. (2009): Untargeted metabolomic profiling as an evaluative tool of fenofibrate-induced toxicology in Fischer 344 male rats. Toxicologic. Pathology; 37: 521-535.

26. Okada,M.; Sano, F.; Ikeda, I.; Sugimoto, J.; Takagi, S.; Sakai, H. and Yanai, T. (2009): Fenofibrate-induced muscular toxicity is associated with a metabolic shift limited to Type-1 muscles in rats. Toxicologic. Pathology; 37: 517-520.

27. Ozbek, E. (2012): Induction of oxidative stress in kidney. International Journal of Nephrology; 1-9.

28. Paget, G. C. and Barnes, J. M. (1964): Toxicity in evaluation of the drug activities. Pharmacometric ed. Pbl. Lournace and bacharachai, Academic press, London and New York, pp. 1-13.

29. Park, G.T.; Jung ,M.; Kim, Y.; Cho, I.; Won, H.; Shin, S.Y.; Lee, W.; Lee, K.J.; Kim, S.; Kim, T.H. and Kim, C.J. (2017): Effect of long-term fenofibrate therapy on serum creatinine and its reversibility in hypertriglyceridemic patients with hypertension. J. Lipid, Atheroscler.; 6(2):89-96.

30. Polanco, N.; Hern?ndez,E.; Gonz?lez, E.; Gutiérrez Mart?nez, E.; Bello,I.; Gutiérrez-
Millet,V.; Garc2, F.; Morales, F. and M. Praga, M. (2009): Fibrate-induced deterioration of renal function. Nefrolog?a; 29(3):208-213.

31. Ronco, C.; Grammaticopoulos, S.; Rosner, M.; Decal, M.; Soni, S. and Lentini, P. (2010): Oliguria, creatinine and other biomarkers of acute kidney injury. Nephrol.; 164: 118-127.

32. Sagheb, M.M.; Namazi, S.; Geramizadeh, B.; Karimzadeh, A.; Oghazian, M.B. and Karimzadeh, I. (2014): Serum cystatin $C$ as a marker of renal function in critically ill patients with normal serum creatinine. Nephrourol. Mon.; 6(2): 15224-15225.

33. Schelleman, H.; Bilker, W.B.; Brensinger,C.M.; Wan, F.; Yang, Y. and Hennessy, S.( 2010): Fibrate/statin initiation in warfarin users and gastrointestinal bleeding risk-The American Journal of Medicine; 123:151-157.

34. Sengupata, P.R. (2016): Medical pharmacology. 2nded. Pbl. New Delhi, Bengaluru, Chennai, Kochi, Kolkata, Mumbai, Hyderabad, Nagpur, Patna, Pune, Vijayawada, pp.259-260.

35. Sica, D.A. (2009): Fibrate therapy and renal function. Curr. Atheroscler. Rep.; 11(5):338-342.

36. Tarantino, N.; Santoro, F.; De Gennaro, L.; Correale, M.; Guastafierro, F.; Gaglione, A.; Di Biase, M. and Brunetti, N.D. (2017): Fenofibrate/simvastatin fixed-dose combination in the treatment of mixed dyslipidemia: safety, efficacy, and place in therapy. Journal Vascular Health and Risk Management; 13:29-41.

37. Trofin, F.; Ciobica, A.; Cojocaru, D.; Chirazi, M.; Honceriu,C.; Trofin, L.; Serban, D.; Timofte, D.; Cojocaru, S. and Emil Anton, E. (2014): Increased oxidative stress status in rat serum after five minutes treadmill exercise. Cent. Eur. J. Med.; 9(5): 722-728.

38. Wu, J.; Song, Y. and Li, H. (2009): Rhabdomyolysis associated with fibrate therapy: review of 76 published cases and a new case report. Eur. J. Cli. Pharmac.; 65:1169-1174.

39. Yang, L.P. and Keating, G.M. (2009): Fenofibric acid: in combination therapy in the treatment of mixed dyslipidemia. Am. J. Cardiovasc. Drugs; 9 (6): 401-409. 


\section{تأثنبر إعطاء الفينو فيبر ات و إنسحابه على كلي ذكور الجرذان البيضاء البالغة (در اسات نسيجية وكيميائية حيوية) أمانى مصطفى أبوعوف- منى عبد اللطيف أبو المعاطى عرفه} قسم التشريح والأجنة ـ كلية الطب ( بنات) - جامعة الأزهر

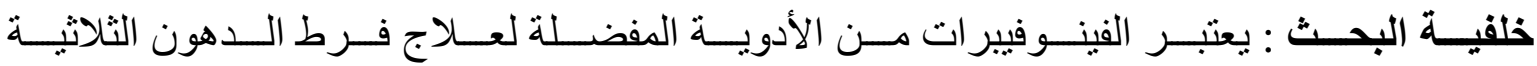

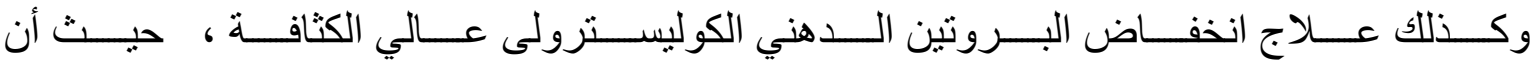
كلاهما من العو امل الخطيرة لمرض القلب و الأوعية الدموية.

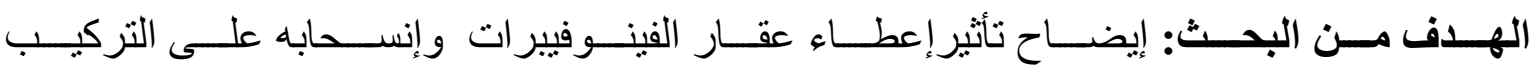
النسيجي ووظيفة الكلى لدى الجرذان الذكور البيضاء البالغين.

مــواد و طـرق البحـث: تـم إســتخدام أربعـين جـرذا مــن الـــكور البيضــاء البــالغين فـي هــذا

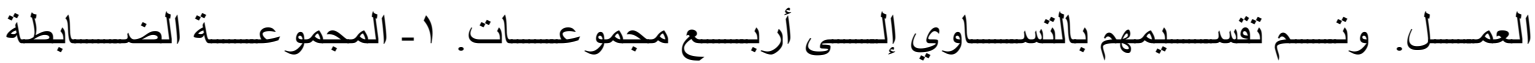

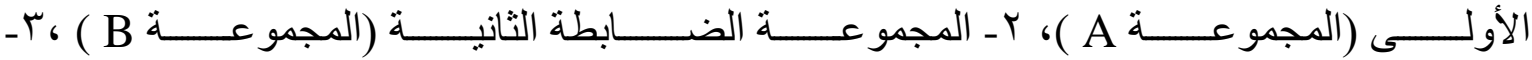

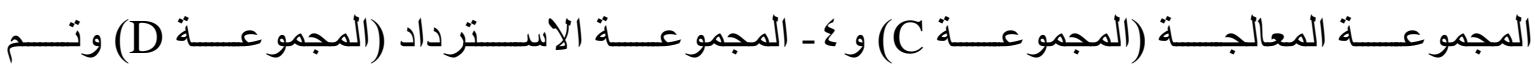

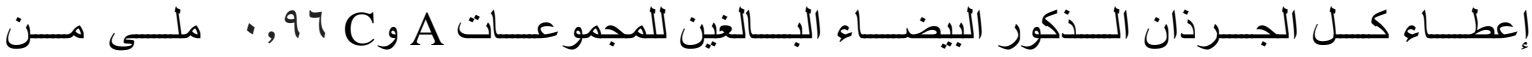

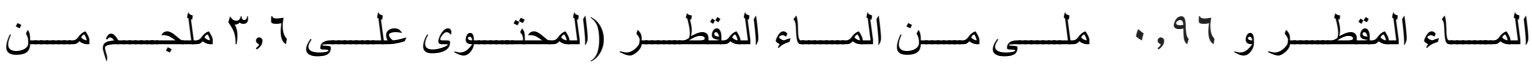

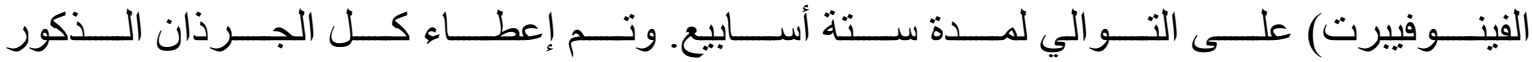

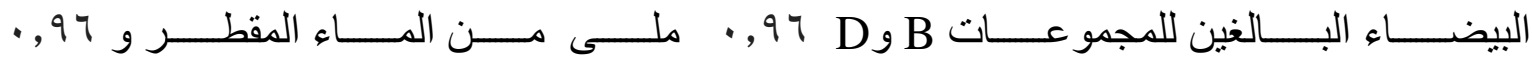

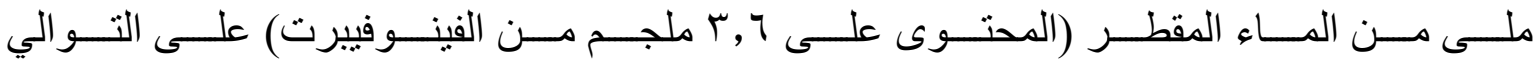

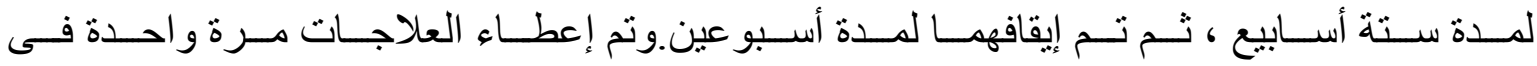

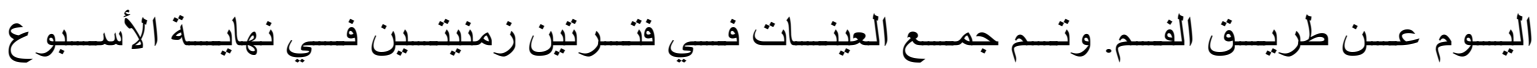

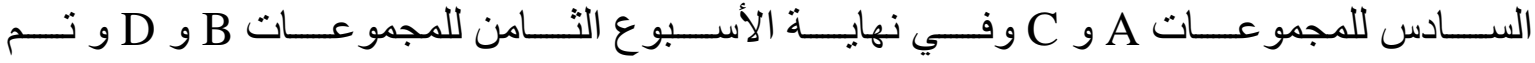

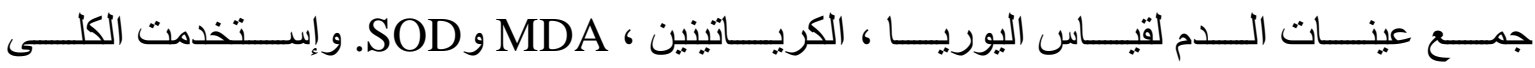
للفحوصات المجهرية والالكترونية والدر اسة المورفومترية.

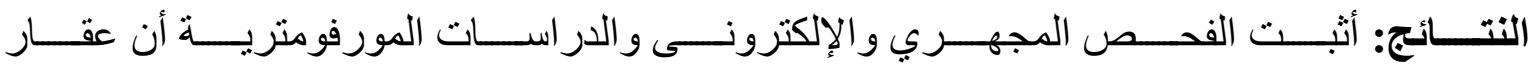

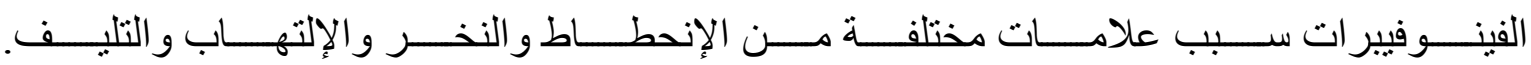

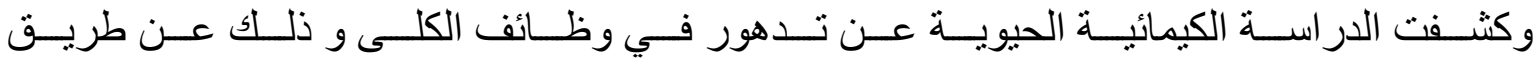




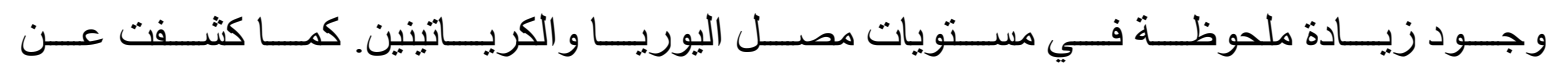

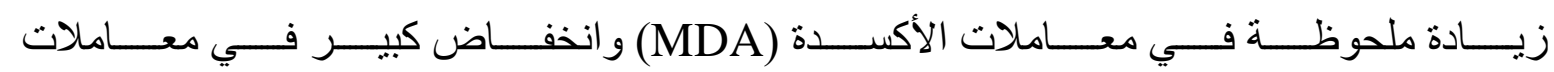

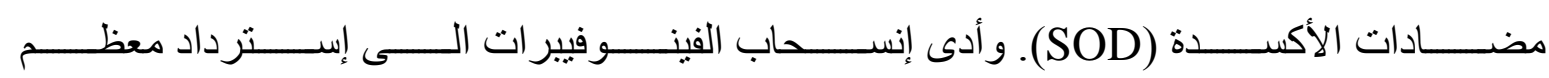
التأثيرات النسيجية وجميع الآثار الكيميائية الحيوية.

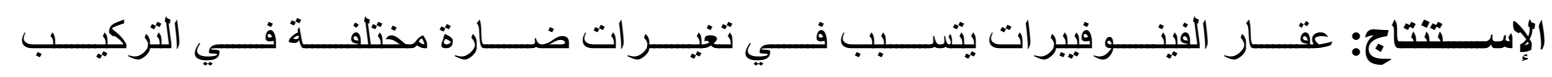

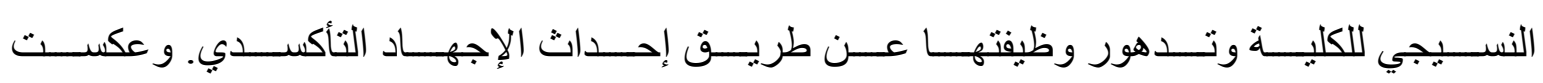
هذه التغيير ات و الإجهاد التأكسدي عند إنسحاب الفينوفيير ات. 